\title{
Impact of integrated nutrient management on some important physical and chemical attributes of soil vis-a-vis performance of bitter gourd
}

\author{
Soumyabrata Chakraborty* and Gyanendra Kumar \\ (West Bengal), INDIA \\ *Corresponding author. E-mail: som1993.kol@gmail.com \\ Received: June 17, 2016; Revised received: November 25, 2016; Accepted: February 21, 2017
}

Department of Agricultural Chemistry and Soil Science, Bidhan Chandra Krishi Viswavidyalaya, Nadia-741252

\begin{abstract}
An experiment has been conducted under AICRP on Soil Test Crop Response (STCR) at the Central Research Farm (Gayeshpur), Bidhan Chandra Krishi Viswavidyalaya, West Bengal to find out the effect of integrated nutrient management in ArkaHarit variety of bitter gourd. The treatments contain different organic and inorganic fertilizer viz. Control (T1), NPK @ 90:60:60 kg/ha (T2), Vermicompost @ 12t/ha (T3), NPK+ Vermicompost @ 3t/ha (T4), FYM @ 25t/ha (T5), NPK+FYM @ 6.25t/ha (T6), Mustard oil cake (MOC) @ 7t/ha (T7), NPK+MOC @ 1.75t/ha (T8). Application of organic and inorganic sources in an integrated manner has resulted higher in yield, physical and chemical parameter such as seed yield $(2815 \mathrm{~kg} / \mathrm{ha})$, aggregate ratio $(0.69)$, mean weight diameter $(0.593 \mathrm{~mm})$, geometric mean weight diameter $(0.679 \mathrm{~mm})$, organic carbon $(1.28 \%)$, CEC (12.88 meq/100g), available nitrogen (208 kg/ha), phosphorus (62 kg/ha), potassium (167 kg/ha) in higher magnitude as compare to the single application of inorganic fertilizer. In maximum cases, the chemical parameters is highest in harvesting stage rather than other stage. Quality characters such as Vitamin A, C, crude fibre are nourished in favourable way due to integrated application of organic and inorganic fertilizers. Based on the performance, it was found that treatment combination of NPK+MOC @ 1.75t/ha (T8) was best among all treatments in most cases for yield, productivity and nutritional aspects of ArkaHarit variety of bitter gourd.
\end{abstract}

Keywords: Bitter gourd, Crop quality, Integrated nutrient management, Physical and chemical properties

\section{INTRODUCTION}

India is regarded as a horticultural paradise (Saravaiya and Patel, 2005), with a vast array of vegetables being cultivated in our country, bitter gourd is considered as one of the most popular and priced fruit vegetable among cucurbits. Bitter gourd (Momordica and charantia L.) is one of the commercially important cucurbitaceous vegetable crops extensively grown throughout the country and it has been used for a long time in various Asian and African traditional medicines (Paul and Raychaudhury, 2010). It is also highly fertilizer responsive crop due to its maximum return. However, the indiscriminate use of chemical fertilizers will lead to potential menace of environment pollution, organic matter reduction, development of nutrient imbalance in plant etc. Therefore, to overcome the negative impacts of natural resources and environment, integrated nutrient management is a holistic approach which utilizes the natural resources in optimum way for sustaining the crop productivity on one hand and to reduce nutrient losses in the environment on the other hand. Efficient use of integrated nutrient management is a pre-requisite for achieving biological productivity of vegetable crops (Sreenivas et al., 2000). The combined use of organic and inorganic sources of plant nutrient not only pushes the production and profitability of field crops, but also helps in maintaining the permanent fertility status of the soil. In the organic sources, organic manures play a vital role for improving soil aeration, water holding capacity, soil structure and crop yield. Among the organic manures, Mustard oil cake is rich in nitrogen, phosphorus and potassium which are essential to maintain soil fertility and growth of plant. Farm yard manure is also a good source of nutrients. Application of farm yard manure resulted in better growth of spider plant as compared to control (Ng'etich et al., 2012).

The present investigation made an attempt to study a) effect of integrated nutrient management of various organic manures and inorganic fertilizers on yield of bitter gourd, b) To study the effect of soil physical and chemical attributes on the performances of bitter gourd, c) To explore the relationship between N, P, K, Vit A, Vit C, Crude fibre of bitter gourd plant and physical and chemical attributes of soil.

\section{MATERIALS AND METHODS}

The entire investigation was planned and executed at Central Research Farm (Gayeshpur), Bidhan Chandra Krishi Viswavidyalaya, Nadia district of West Bengal during 2013 which is located at $23^{\circ} \mathrm{N}$ latitude and $89^{\circ}$ 
E longitude at an elevation of $9.75 \mathrm{~m}$ above mean sea level. The soil of the experimental site is loam to silty loam in texture with around $0.90 \%$ of organic carbon, $213.6 \mathrm{~kg} / \mathrm{ha}$ available nitrogen, $24.57 \mathrm{~kg} / \mathrm{ha}$ available phosphorus, $102.48 \mathrm{~kg} / \mathrm{ha}$ available potassium, $\mathrm{pH}$ 8.08 and adequate amount of moisture percentage. The experimental site is under subtropical humid region with maximum and minimum temperature of $34^{\circ} \mathrm{C}$ and $20{ }^{\circ} \mathrm{C}$ respectively which receives an average annual rainfall of approximately $1576 \mathrm{~mm}$.

The experiment consists of eight treatments including combination of organic and inorganic fertilizers.

T1- No use of fertilizer or organic manure(control)

T2- NPK through fertilizers (90:60:60)

T3- NPK through vermicompost(12 t/ha)

T4- NPK through vermicompost (3t/ha) and fertilizers (90:60:60)

T5- NPK through FYM (Farm yard manure) (25 t/ha) such as poultry organic manure

T6- NPK through FYM (6.25 t/ha) and fertilizers (90:60:60)

T7- NPK through MOC (7t/ha)

T8- NPK through MOC (Mustard oil cake) (1.75t/ha) and fertilizers (90:60:60)

Various chemical and the physical parameters were determined followed by standard methodologies. Fresh bitter gourd samples were collected and analyzed for quality parameters (Vitamin A, Ascorbic acid, crude fiber). Ascorbic acid content of the Bitter gourd was estimated by titration with 2.6- dichlorophenol indophenol sodium salt solution (Sadasivam and
Manikam, 1992). Vitamin A content was also estimated by following the method of Sadasivam and Manikam, 1992. The total nitrogen, phosphorous, potassium and yield of vine were also analyzed. The observed data was subjected for standard LSD analysis (using SPSS software, Version 20) and testing for the significance of treatments is made. The multiple comparisons are made using DMRT (Duncan Multiple Range Comparison) technique. The $5 \%$ probability level is regarded as statistically significant.

\section{RESULTS AND DISCUSSION}

Seed yield of bitter gourd crop: There was a significant (5\% probable level of significance) response of bitter gourd to Mustard Oil Cake (MOC) and FYM (Table 1) application over recommended dose of NPK (T2) as well as control (T1). The responses varied from 109 to $187 \%$ over the recommended dose of NPK. However, sole application of MOC and FYM also registered significant yield increase over T2. An increase in bitter gourd yield with NPK+ MOC; NPK+FYM application has also been reported by Ghosh et al. (2011). Among the different treatments T8 recorded highest yield $(2815 \mathrm{~kg} / \mathrm{ha})$ compared to others. The application of organic manure has numerous advantages, such as, improving soil physical property parameters, i.e., water holding capacity, water movement, infiltration rate, bulk density, porosity, tilth, aeration, soil structure, aggregate stability etc. Organic inputs to soil help in improving the aggregate stability (Bandyopadhyay et al., 2010).

Table 1. Seed yield of bitter gourd as influenced by integrated nutrient management during 2013.

\begin{tabular}{llc}
\hline Treatment & Treatment details & Yield of Bittergourd (kg/ha) \\
\hline T1 & Control & $896^{\mathrm{f}}$ \\
T2 & Recommended dose (RD) of NPK (90:60:60) & $1504^{\mathrm{e}}$ \\
T3 & Vermicompost @ 12.0 t/ha & $1652^{\mathrm{d}}$ \\
T4 & RD of NPK (90:60:60)+Vermicompost @ 3.0 t/ha & $2119^{\mathrm{c}}$ \\
T5 & FYM@ 25.0 t/ha & $2452^{\mathrm{b}}$ \\
T6 & RD of NPK (90:60:60)+FYM@6.25 t/ha & $2800^{\mathrm{a}}$ \\
T7 & Mustard Oil Cake @ 7.0 t/ha & $2474^{\mathrm{b}}$ \\
T8 & RD of NPK (90:60:60)+ Mustard Oil Cake @ 1.75 t/ha & $2815^{\mathrm{a}}$ \\
LSD (P=0.05) & & 94.02 \\
\hline
\end{tabular}

Table 2. Bulk density and aggregate analysis of the experimental soil under different treatment combinations.

\begin{tabular}{|c|c|c|c|c|c|}
\hline Treatment & $\begin{array}{c}\text { Bulk Density } \\
\left(\mathrm{Mg} / \mathrm{m}^{3}\right)\end{array}$ & $\begin{array}{l}\text { Aggregate } \\
\text { ratio }\end{array}$ & $\begin{array}{c}\text { Aggregate } \\
\text { Stability (\%) }\end{array}$ & $\begin{array}{c}\text { Mean weight } \\
\text { diameter (mm) }\end{array}$ & $\begin{array}{c}\text { Geometric mean } \\
\text { diameter }(\mathrm{mm})\end{array}$ \\
\hline$\overline{\mathrm{T} 1}$ & $1.24^{\mathrm{a}}$ & $0.15^{\mathrm{f}}$ & $2.00^{\mathrm{h}}$ & $0.427^{\mathrm{g}}$ & $0.603^{\mathrm{e}}$ \\
\hline T2(NPK) & $1.20^{\mathrm{b}}$ & $0.15^{\mathrm{f}}$ & $2.20^{\mathrm{g}}$ & $0.429^{\mathrm{g}}$ & $0.607^{\mathrm{e}}$ \\
\hline $\mathrm{T} 3(\mathrm{VC})$ & $1.16^{\mathrm{c}}$ & $0.19^{\mathrm{e}}$ & $2.41^{\mathrm{f}}$ & $0.518^{\mathrm{c}}$ & $0.623^{\mathrm{d}}$ \\
\hline $\mathrm{T} 4(\mathrm{NPK}+\mathrm{VC})$ & $1.09^{\mathrm{d}}$ & $0.35^{\mathrm{d}}$ & $2.43^{\mathrm{e}}$ & $0.526^{\mathrm{b}}$ & $0.633^{\mathrm{b}}$ \\
\hline T5(FYM) & $1.08^{\mathrm{d}}$ & $0.61^{\mathrm{c}}$ & $2.82^{\mathrm{c}}$ & $0.463^{f}$ & $0.621^{\mathrm{d}}$ \\
\hline $\mathrm{T}_{6}(\mathrm{NPK}+\mathrm{FYM})$ & $1.10^{\mathrm{d}}$ & $0.65^{\mathrm{b}}$ & $2.70^{\mathrm{d}}$ & $0.503^{\mathrm{d}}$ & $0.635^{\mathrm{b}}$ \\
\hline $\mathrm{T} 7(\mathrm{MOC})$ & $1.12^{\mathrm{d}}$ & $0.69^{\mathrm{a}}$ & $2.84^{\mathrm{a}}$ & $0.480^{\mathrm{e}}$ & $0.622^{\mathrm{c}}$ \\
\hline $\mathrm{T}_{8}(\mathrm{NPK}+\mathrm{MOC})$ & $1.12^{\mathrm{d}}$ & $0.69^{\mathrm{a}}$ & $2.80^{\mathrm{b}}$ & $0.593^{\mathrm{a}}$ & $0.679^{\mathrm{a}}$ \\
\hline Mean & 1.14 & 0.43 & 2.52 & 0.492 & 0.628 \\
\hline $\operatorname{LSD}(0.05)$ & 0.033 & 0.003 & 0.018 & 0.009 & 0.011 \\
\hline$\underline{\operatorname{S.Em}}( \pm)$ & 0.0110 & 0.0011 & 0.0061 & 0.0031 & 0.0035 \\
\hline
\end{tabular}

Mean values followed by same letter are not significantly different $(\mathrm{P}<0.05)$ by Duncan's Multiple Range Test. 


\section{Soumyabrata Chakraborty and Gyanendra Kumar/ J. Appl. \& Nat. Sci. 9 (1): 556 - 561 (2017)}

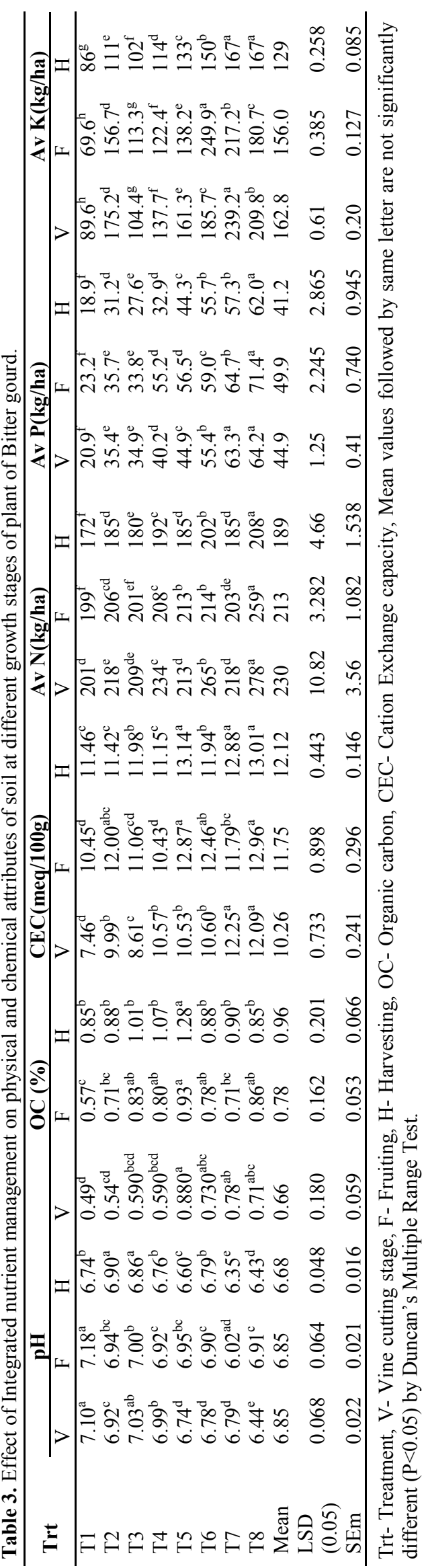

Physical attributes of the soil

Bulk density: The highest value of bulk density was observed in $\mathrm{T} 1$ or control $(1.24 \mathrm{Mg} \mathrm{m}-3)$ and the lowest value $1.08 \mathrm{Mg} \mathrm{m}-3$ was observed in the treatments having FYM only (T5). Lower values of $\mathrm{BD}$ also recorded in other treatment combinations having organic materials with inorganic fertilizer combination i.e. T6, T7, and T8 (Table 2). This result was similar to Gulser et al. (2006). He proposed that increased organic matter content decreased soil bulk density.

Aggregate ratio: The lowest aggregate ratio found in control and highest aggregate ratio found in $\mathrm{T} 8$ and $\mathrm{T} 7$ (Table 2). The results showed that NPK with organic amendments caused $57 \%$ to $78 \%$ higher aggregate ratio. This is due to the fact that organic matters act as a chelating agent to bind the soil particle thus help in the soil aggregation.

Aggregate Stability: Aggregate Stability of the experimental soil under different treatments were significantly differed (5\% probability level of significance) and varied from 2.0 to 2.84 and $39 \%$ to $80 \%$ respectively (Table 2). The highest value was observed in treatment T7 (MOC@7 t/ha) and the lowest value in case of Control (T1). From the results it was found that sole application of FYM and MOC seemed to be better as compared to vermicompost in enhancing aggregate stability, contributing $29.6 \%, 29.0 \%$ and $17.1 \%$ over control respectively.

Mean weight diameter: Highest and lowest mean weight diameter was found in the treatment T8 and control plot respectively (Table 2), although the mean weight diameter values of control and only NPK treated soil were statistically at par. The increase in mean weight diameter could be attributed to the input of addition of fresh organic residues, FYM and available C (Kumar et al., 2013) to the soil resulting in enhanced microbial activity and thus binding of aggregates. However, the variation of mean weight diameter among the treated organics might be influenced by either bio-chemical composition.

Geometric mean diameter: Highest and lowest geometric mean diameter was also found in the treatment T8 and control plot respectively (Table 2). Organic amendments seized this structural parameter in the order of MOC $>$ FYM $>$ VC consisting of $11.1 \%, 5.03$ $\%$ and $4.73 \%$ (over control) and $10.6 \%, 4.4 \%$ and $4.1 \%$ (over $100 \%$ fertilizer treatment) respectively, when applied with full dose of NPK. This is due to the fact that organic inputs provide energy and nutrients to soil organism that drive soil process, which stimulate production of organic compound essential for soil aggregate size, focused by geometric mean diameter (Tate, 1987).

\section{Chemical properties}

Soil pH: With respect to soil reaction $(\mathrm{pH})$, all the treatments showed nearly neutral $\mathrm{pH}$ at all three stages. 
Table 4. Effect of INM on nutritional quality aspects of bitter gourd.

\begin{tabular}{lcccccc}
\hline Treatment & N in plant (\%) & P in plant (\%) & K in plant (\%) & Vitamin A (IU) & Vitamin C (mg/100g) & Crude fibre (\%) \\
\hline $\mathrm{T}_{1}$ & $7.53^{\mathrm{g}}$ & $5.52^{\mathrm{b}}$ & $1.55^{\mathrm{b}}$ & $352.22^{\mathrm{g}}$ & $87.77^{\mathrm{c}}$ & $44.17^{\mathrm{a}}$ \\
$\mathrm{T}_{2}$ & $7.93^{\mathrm{f}}$ & $4.08^{\mathrm{d}}$ & $1.33^{\mathrm{c}}$ & $537.06^{\mathrm{f}}$ & $80.33^{\mathrm{d}}$ & $33.00^{\mathrm{d}}$ \\
$\mathrm{T}_{3}$ & $10.77^{\mathrm{e}}$ & $4.93^{\mathrm{bcd}}$ & $1.10^{\mathrm{d}}$ & $612.60^{\mathrm{d}}$ & $93.61^{\mathrm{b}}$ & $41.67^{\mathrm{c}}$ \\
$\mathrm{T}_{4}$ & $12.23^{\mathrm{c}}$ & $5.28^{\mathrm{bc}}$ & $0.67^{\mathrm{e}}$ & $686.60^{\mathrm{c}}$ & $88.71^{\mathrm{c}}$ & $43.00^{\mathrm{b}}$ \\
$\mathrm{T}_{5}$ & $12.39^{\mathrm{b}}$ & $5.61^{\mathrm{b}}$ & $1.08^{\mathrm{d}}$ & $730.06^{\mathrm{a}}$ & $110.45^{\mathrm{a}}$ & $41.17^{\mathrm{c}}$ \\
$\mathrm{T}_{6}$ & $11.51^{\mathrm{d}}$ & $4.75^{\mathrm{bd}}$ & $2.09^{\mathrm{a}}$ & $557.46^{\mathrm{e}}$ & $67.29^{\mathrm{e}}$ & $41.17^{\mathrm{c}}$ \\
$\mathrm{T}_{7}$ & $12.23^{\mathrm{c}}$ & $4.45^{\mathrm{cd}}$ & $0.55^{\mathrm{f}}$ & $99.55^{\mathrm{h}}$ & $69.28^{\mathrm{e}}$ & $31.50^{\mathrm{e}}$ \\
$\mathrm{T}_{8}$ & $13.43^{\mathrm{a}}$ & $7.18^{\mathrm{a}}$ & $0.28^{\mathrm{g}}$ & $842.01^{\mathrm{a}}$ & $60.17^{\mathrm{f}}$ & $44.33^{\mathrm{a}}$ \\
Mean & 11.00 & 5.23 & 1.08 & 552.19 & 82.20 & 40.00 \\
LSD $(0.05)$ & 0.135 & 0.883 & 0.031 & 3.411 & 2.562 & 0.761 \\
S.Em $( \pm)$ & 0.045 & 0.291 & 0.010 & 1.125 & 0.845 & 0.251 \\
\hline
\end{tabular}

Mean values followed by same letter are not significantly different $(\mathrm{P}<0.05)$ by Duncan's Multiple Range Test.

Table 5. Simple correlation coefficient between soil properties and quality parameters.

\begin{tabular}{lccccccc}
\hline Soil Properties & $\begin{array}{c}\text { N in plant } \\
(\%)\end{array}$ & $\begin{array}{c}\text { P in plant } \\
(\%)\end{array}$ & $\begin{array}{c}\text { K in plant } \\
\mathbf{( \% )}\end{array}$ & $\begin{array}{c}\text { Vit. A } \\
(\mathbf{I U})\end{array}$ & $\begin{array}{c}\text { Vit. C } \\
(\mathbf{m g} / \mathbf{1 0 0 g})\end{array}$ & $\begin{array}{c}\text { Crude fibre } \\
(\mathbf{\%})\end{array}$ & $\begin{array}{c}\text { Yield } \\
(\mathbf{k g} / \mathbf{h a})\end{array}$ \\
\hline pH & $-0.65^{* *}$ & $-0.538^{* *}$ & $0.648^{* *}$ & 0.26 & $0.503^{*}$ & 0.136 & $-0.552^{* *}$ \\
Org C (\%) & 0.307 & 0.144 & -0.107 & $0.478^{*}$ & 0.216 & 0.125 & 0.111 \\
CEC (meq/100g) & $0.612^{* *}$ & 0.313 & $-0.419^{*}$ & 0.084 & $-0.497^{*}$ & -0.09 & $0.613^{* *}$ \\
BD (g/cc) & 0.272 & 0.305 & -0.342 & $-0.659^{* *}$ & $-0.468^{*}$ & $-0.471^{*}$ & 0.202 \\
AR & $0.824^{* *}$ & 0.313 & -0.292 & 0.043 & $-0.765^{* *}$ & -0.05 & $0.925^{* *}$ \\
AS (\%) & $0.424^{*}$ & 0.052 & -0.145 & 0.014 & $-0.784^{* *}$ & $-0.498^{*}$ & $0.678^{* *}$ \\
MWD & 0.303 & -0.357 & $-0.451^{*}$ & 0.31 & $-0.742^{* *}$ & 0.037 & $0.58^{* *}$ \\
GMD & 0.386 & -0.293 & $-0.445^{*}$ & 0.339 & $-0.729^{* *}$ & 0.236 & $0.661^{* *}$ \\
Av. N(kg/ha) & $0.481^{*}$ & -0.331 & -0.198 & 0.393 & -0.809 & 0.191 & $0.793^{* *}$ \\
Av. P (kg/ha) & $0.571^{* *}$ & -0.068 & $-0.485^{*}$ & 0.167 & $-0.847^{* *}$ & 0.083 & $0.791^{* *}$ \\
Av K(kg/ha) & $0.755^{* *}$ & 0.229 & -0.391 & -0.079 & $-0.917^{* *}$ & -0.261 & 0.899 \\
\hline
\end{tabular}

In most of the cases $\mathrm{pH}$ declined at harvesting stages than earlier vine cutting and fruiting stage. The highest value were associated with the treatment T2 having Vermicompost application@12t/ha and lowest values were observed in the treatment T7 (Mustard oil cake application @ 7t/ha) at harvesting stage. The soil pH reduced significantly (5\% level of significance) with MOC application than Vermicompost application due to more organic acid production during its decomposition (Table 3). Similar observations were recorded by Patil et al. (2003). He conducted an experiment in ricewheat-greengram sequence which showed that MOC reduced $\mathrm{pH}$ significantly in NPK and MOC treatments. Oxidisable organic carbon: Organic carbon content of soil acts as an indicator of soil structure, stability, nutrient retention and soil erosion. The lowest values of organic carbon were found in control T1 (0.85\%) and highest value recorded in T5 (1.28\%) respectively at harvesting stage (Table 3). Kumar et al., (2000) reported that the application of organic manure in conjunction with recommended dose of fertilizers help to build up the soil organic carbon as compared to control.

Cation exchange capacity: Cation exchange capacity is a very important soil property influencing soil structure stability, nutrient availability, soil $\mathrm{pH}$ and the reaction to fertilisers and other ameliorants (Hazleton and Murphy, 2007). In most of the cases CEC increased at harvesting stages than earlier vine cutting and fruiting stage (Table 3). The highest value were asso- ciated with the treatment T5 (NPK+ Mustard oil cake application@7t/ha) and lowest values were observed in the treatment T2 (Recommended dose of NPK) at harvesting stage. Similar observations were also noted by Aziz et al., (2012). He conducted an experiment in Soybean crop in which the soil was silty clay loam in nature and showed that combined use of organic and inorganic fertilizers can increase more CEC than inorganic fertilizers.

Available nitrogen: There was gradual decline of available nitrogen from vine cutting stage to harvesting stage in all the treatments. The available $\mathrm{N}$ content of the soil under various treatments at harvesting stage was as follows- $\mathrm{T} 8>\mathrm{T} 6>\mathrm{T} 4>\mathrm{T} 2=\mathrm{T} 5=\mathrm{T} 7>\mathrm{T} 3>\mathrm{T} 1$. The addition of organic residues along with inorganic fertilizer i.e. integration of FYM, VC and MOC with NPK (T8, T6 and T4), caused an increase in higher magnitude as compare to the single application of inorganic fertilizer (T2) (Table 3). The highest available $\mathrm{N}$ content in T8 (NPK + MOC@1.75t/ha) is probably due to the fact that decomposition of Mustard Oil Cake produces some organic ligands which helps to increase its availability to plants and at the same time due to quick mineralization of $\mathrm{MOC}, \mathrm{N}$ is released in the soil (BARC, 1997; Sheeba and Chellamuthu, 1999). Chakraborty (2007) also reported the similar results. He reported that a significant increase in available $\mathrm{N}$ content in soil upon continuous incorporation of FYM with inorganic fertilizer in 21 years old long term experiment. 
Available phosphorus and potassium: The available phosphorus was also highest in T8 at harvesting stage (Table 3) due to the fact that decomposition of Mustard Oil Cake released organic compound which may increase $\mathrm{P}$ availability by blocking $\mathrm{P}$ adsorption site or via anion exchange (Nambiar, 2002).

Effect of integrated nutrient management on quality characters of bitter gourd: The N, P, K content in plant and nutritional aspects like Vitamin A, Vitamin $\mathrm{C}$ content and crude fibre percentage under different treatments is presented in Table 4. The nutritional quality of Bitter gourd was enhanced in suitable way due to application of FYM, MOC and inorganic fertilizers than control. The N, P content and Vit A and crude fibre content was maximum in Mustard oil cake with fertilizers (T8). The Vit $\mathrm{C}$ or ascorbic acid content was maximum in T5 treated with FYM with poultry manure. Kameswari and Narayanamma (2011) reported that application of poultry manure can improve the quality characters like Total soluble solid (TSS) and ascorbic acid content of ridge gourd (Luffa acutangula).

Corelation studies: Simple Correlation coefficient (r) between soil properties and quality parameters of plants were recorded in Table 5. Soil $\mathrm{pH}$ bears a highly significant positive correlation with $\mathrm{K}$ in plant (\%) $\left(\mathrm{r}=0.648^{* *}\right.$ at $1 \%$ level of significance) Vit $\mathrm{C}(\mathrm{r}=$ $\left.0.503^{*}\right)$ whereas Org. C showed positive correlation with Vit $\mathrm{A}\left(\mathrm{r}=0.478^{*}\right)$ and $\mathrm{CEC}$ recorded significant positive correlation with $\mathrm{N}$ in plant (\%) and yield $\left(\mathrm{r}=0.613^{* *}\right)$. Vitamin $\mathrm{A}$ is an important component of bitter gourd which contains various organic compounds such as retinol, retinoic acid. Application of organic components such as FYM, mustard oil cake in soil the organic compounds of Vitamin A also increases which also increases organic carbon. CEC is important indication of soil fertility which control many plant nutrients and thereby increases yield. However, most of the soil properties showed a significant negative correlation with vitamin $\mathrm{C}$ content except soil $\mathrm{pH}$. In lower $\mathrm{pH}$ values the more $\mathrm{H}+$ ions are present. As such, lower the $\mathrm{pH}$ of soil the more $\mathrm{H}+$ ions present to oxidise the ascorbic acid. BD showed negative correlation with Vitamin A $\left(\mathrm{r}=-0.659^{* *}\right)$, Vitamin C $\left(\mathrm{r}=-0.468^{*}\right)$ and crude fibre $\left(\mathrm{r}=-0.471^{*}\right)$.

\section{Conclusion}

Integrated nutrient management treatments rendered their significant effect on almost all the physical and chemical parameters and yield attributing characters of bitter gourd cv. ArkaHarit. Therefore, the results revealed from the experiment that, application of inorganic fertilizer along with organic manure such as MOC, FYM, Vermicompost not only increase the yield of the crop but also improve the nutrient status of soil. Among all the treatments T8 (NPK+ Mustard oil cake@1.75t/ha) showed best result with respect to seed yield (2815 kg/ha) and productivity. In the physical parameters aggregate ratio, mean weight diameter, geometric mean weight diameter is $0.69,0.593 \mathrm{~mm}$, $0.679 \mathrm{~mm}$ respectively in $\mathrm{T} 8$ treatment which was highest than other treatments. Organically amended soils (FYM, Vermicompost and MOC) along with recommended dose of NPK recorded lower $\mathrm{pH}$. The lowest values of organic carbon were found in control T1 $(0.65 \%)$ and highest value recorded in T5 (1.28\%) at harvesting stage. The addition of organic residues along with inorganic fertilizer i.e. integration of FYM, VC and MOC with NPK (T8, T6 and T4) caused an increase in $\mathrm{CEC}$, available nitrogen, phosphorus in higher magnitude as compare to the single application of inorganic fertilizer (T2) and control. Among the 8 different treatments, T8 recorded highest CEC, available nitrogen, phosphorus in vine cutting, fruiting and harvesting stage. On the other hand, control treatment was the lowest performer for the said characters. Thus it may be concluded that, NPK+MOC @ $1.75 \mathrm{t} / \mathrm{ha}$ (T8) is putatively selected as best one among other treatments for fostering crop growth and improvement of soil health and sustainability.

\section{REFERENCES}

Aziz, M. A., Amees, A. T., Mahdi, S. S. and Ali, T. (2012). Effect of integrated nutrient management on physical properties using soybean (Glycine max (L.) as indicator crop under temperate conditions. International Journal of Current Research ,4:203-207

Bandyopadhyay, P. K., Saha, S., Mani, P. K. and Mandal, B. (2010). Effects of organic inputs on aggregate associated organic carbon concentration under long-term rice-wheat cropping system. Geoderma, 154: 379-386

BARC (1997). Bangladesh Agricultural Research Council. Fertilizer Recommendation Guide-1997. BARC, Soils pub., No- 41, Bangladesh Agril. Res. Coun., Farmgate, New Airport Road, Dhaka-1215 Pp. 25: 180

Chakraborty, S. (2007). Studies on the dynamics of phosphorus in soils under long -term fertility experiments with rice based cropping systems, $\mathrm{Ph}$. D. Thesis, Bidhan Chandra Krishi Viswavidyalaya, Mohanpur, West Bengal, India.

Ghosh, C., Mandal, J. and Chattopadhyay, G. N. (2011). Proportional substitution of chemical fertilizers with vermicompost on production potential of some vegetable crops. Int. symp. on system intensification towards food and livelihood security held at Farmers' Training Centre (FTC) Kalyani, BCKV, Nadia, West Bengal, India, during February 24 to27, 2011

Gulser, C. (2006). Effects of forage cropping treatments on soil structure and relationship with fractal dimensions. Geoderma, 131: 33-44

Hazleton, P. A. and Murphy, B. W. (2007). Interpreting soil test results: what do all the numbers mean? CSIRO Publishing: Melbourne.

Kameswari, P. L. and Narayanamma, M. (2011). Influence of integrated nutrient management in ridge gourd [Luffa 
acutangula (Roxb.) L.]. Journal of Research A.N.G.R.A.U., 39: 16-20

Kumar, R., Singh, G., Walis, S.S., Kumar, R. and Singh G. (2000). Long-term effect of manures and fertilizers on rice yield and soil fertility status in rice-wheat system. Environmental Ecology, 18(3): 546-549

Kumar. J., Rawat, K. S., Singh, J., Singh, A. and Rai, A. (2013). Soil aggregation dynamics and Carbon sequestration. Journal of Applied and Natural Science, 5(1): 250-267

Nambiar, K.K.M. and Abrol, I.P. (1989). Long term fertilizer experiments in India: An overview. Fert. News., 34(4): $11-20$

Ng'etich, O. K., Aguyoh, J. N. and Ogweno, J. O. (2012). Effects of composted farmyard manure on growth and yield of spider plant (Cleome gynandra). International Journal of Science and Nature, 3(3): 514-520

Patil, P. V., Chalwade, P. B., Solanke, A. S. and Kulkarni, V. K. (2003). Effect of fly ash and FYM on physicochemical properties of vertisols. Journal of Soils and Crops, 13(1): 59-64
Paul, A. and Raychaudhuri, S. S. (2010). Medicinal uses and molecular identification of two Momordi and cacharantia varieties: a review. Electronic Journal of Biology, 6 (2): $43-51$

Sadasivam, S. and Manikam, A. (1992). Biochemical Methods for Agricultural Sciences, Willey Eastern Limited, New Delhi Pp. 189-191

Saravaiya, S. N. and Patel, M. B. (2005). DBM (Diamond back moth): the most notorious pest of cauliflower and its management strategies. Agrobios Newsletter, 3:23-24

Sheeba, S. and Chellamuthu, S. (1999). Long-term influence of organic and inorganic fertilization on the macronutrient status of Inceptisols. J. Indian Soc. Soil Sci., 47 (4): 803-804

Sreenivas, C., Muralidhan, S. and Rao, M. S. (2000). Yield and quality of ridge gourd fruits as influenced by different level of inorganic fertilizers and Vermicompost. Annals of Agricultural Research, 21: 262-266

Tate, R. L. (1987). Soil organic matter, biological and ecological effects. John Wiley and Sons, New York. 